
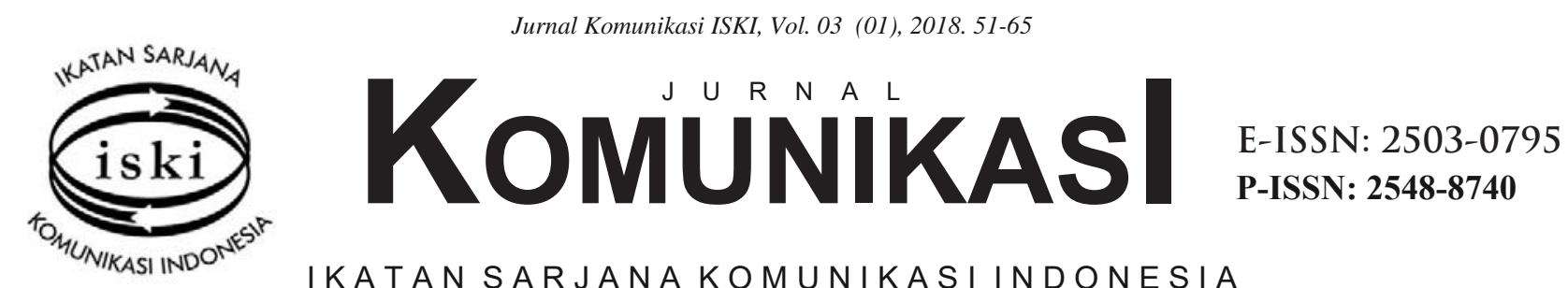

IKATAN SARJANA KOMUNIKASIINDONESIA

\title{
Social Media and the Political Campaign Industry in Indonesia
}

\author{
http://dx.doi.org/10.25008/jkiski.v3i1.124 \\ Muninggar Sri Saraswati \\ Swiss German University \\ Jl. Jalur Sutera Barat Kav. 15 Alam Sutra, Tangerang 15143 - Indonesia \\ muninggar.saraswati@sgu.ac.id
}

\begin{abstract}
The use of social media has been expanding rapidly that it has been recently overwhelmed not only players in Indonesian electoral and political scenes but also general public. While previous studies appeared to put an emphasis on the technological forces (the social media itself), the political forces (the political parties, politicians or candidates) or cultural forces (the voters or social media users) alone to understand the development, this article argues that the use of social media in electoral campaigning requires mediation by economic forces as represented by the political campaign industry. Based on a series of in-depth interviews with key politicians, campaigners, social media users and media people, the involvement of the political campaign industry in the commodification of social media is found. Such a commodification has resulted in the emergence of buzzing, social media users mobilization and social media monitoring.
\end{abstract}

Keywords: Political Campaign Industry, Social Media, Commodification, Electoral Campaign, Online Politics

\begin{abstract}
Abstrak
Penggunaan media sosial berkembang pesat sehingga membuat pemain dalam pemilihan dan pemilihan politik di Indonesia beberapa tahun ini merasa kewalahan. Penelitian sebelumnya cenderung lebih menekankan kekuatan teknologi (yaitu media sosial itu sendiri), kekuatan politik (partai politik, politisi atau kandidat) atau kekuatan budaya (pemilih atau pengguna media sosial) saja untuk memahami perkembangan tersebut. Penelitian ini berpendapat bahwa penggunaan media sosial dalam kampanye pemilihan umum memerlukan mediasi oleh kekuatan ekonomi yang diwakili oleh industri kampanye politik. Berdasarkan serangkaian wawancara mendalam dengan politisi kunci, juru kampanye, pengguna media sosial dan media, ditemukan bahwa keterlibatan industri kampanye politik dalam komodifikasi media sosial. Komoditas semacam itu telah menghasilkan munculnya aktivitis seperti buzzing, social media users mobilisation dan social media monitoring.

Kata kunci: Industri Kampanye Politik, Media Sosial, Komodifikasi, Kampanye Pemilu, Politik Online
\end{abstract}

Copyright (๑ 2017 Ikatan Sarjana Komunikasi Indonesia. All rights reserved

\section{Introduction}

This article looks into social media campaigning in Indonesia. It analyses the emergence of certain social media campaigning activities by name of buzzing, social media users mobilization and social media monitoring. Such activities, which emerged in the 2012
Jakarta election, have since been replicated in different electoral settings in Indonesia. Central in this study is the economic process, in this case is commodification that play a significant role in facilitating political elite's use of social media for campaigning. It is not suggested that social media are the main cause of the 
commodification of information in election campaigns. Instead, this article argues that the use of social media in election campaigns are contributed by the political campaign industry on the broader context of prevailing market and political power in specific electoral settings.

However, unlike political marketing studies that focus on the political marketing practices (Ahmad \& Popa, 2014), it concentrates on the broader political economic aspects that shape the use of social media. Therefore, rather than social media texts or content, this study focuses on examining the offline process in the real world within which social media campaigning is mediated by the political campaign industry in Indonesia. This article considers social media campaign as commodity and it understands commodification as "a process of creating exchange value in the content of communication that draws an entire complex of social relations into the orbit of commodification" (Mosco, 2009: 134).

This study is dedicated to answer the question "how do the political campaign industry commodify in social media for campaigning? To answer that question, this study specifically looked at the 2012 Jakarta gubernatorial election settings as the marker of the extensive use of social media in the context of political and electoral campaigns and the emergence of the political campaign industry in Indonesian political setting, to look into the ways the political campaign industry engage in the commodification of social media.

In so doing, it is expected that this article add another view in the on-going discussions of online campaigning or the Internet-based politics that increasingly become more predictable. Obviously, there has been a shift of the scholarly studies pertaining to social media use in the political and electoral context in Indonesia. Previous studies focused mainly on examining the positive contribution of the new technology to the development of democracy (Nuswantoro, 2014; Sobri, 2012). These studies view social media as alternative media through which voters engage in political deliberation and participation (Nuswantoro, 2014; Suaedy,
2014). The studies from this stream often look into details of social media's technological features and their subsequent impacts on politics, particularly electoral processes in Indonesia (Ibrahim, Abdillah, Wicaksono, \& Adriani, 2015; Utomo, 2013; Wijayanto, 2010; Yuliatiningtyas, 2014).

Such a perspective might be inspired by the significance of the Internet in contributing not only to resisting but, more importantly, to ending the authoritarian rule of Suharto (Hill \& Sen, 2000). One of the most common views about social media is that it enables citizens to discuss issues alternative to those which are determined by the political and economic elites, and which are therefore commonly produced and distributed through conventional media. More recent studies tend to put an emphasis on the negative consequences of the social media use in the political and electoral realm such as the production and distribution of fake news or hoax (Syahputra, 2017). Social media has now been appeared as the culprits of the mêlée in the political and electoral scene that has gone beyond the online sphere, which needs to be disciplined.

Thus, this study does not follow either of the dominant views above. It underlines that our understanding of the contribution of social media in the political and electoral scenes should not be based the technological forces (that is, the social media), the political forces (the political parties, politicians or candidates) or cultural forces (the voters or social media users) alone. Instead, this study highlights an argument that the use of social media in electoral campaigning requires mediation by economic forces as represented by the political campaign industry.

\section{Theoretical Framework}

Studies on commodification of mass media, centers on the idea that content or information is subject to commodification. Media-based commodification ranges from entertainment (Grigsby, 1998; Stiernstedt, 2008), sports (Ben-Porat, 1998; McKay \& Miller, 1991) to politics (Mancini, 2011). The 
later is are particularly susceptible to commodification during elections because elections intensify political communication, as signified by the increasing number of political communicators, political marketing efforts as well as political messages or contents to reach out many voters as possible (Petrocik, 1996; Petrocik, Benoit, \& Hansen, 2003; Trent \& Friedenberg, 1995). Elections also give rise to periods when media consumption of political issues increase, arguably as voters need to make informed choices for voting. Commodification of election information or content has been indicated by the involvement of election business or campaigning industry such as public relations, advertising, political marketing, polling in political campaigns (Thurber \& Nelson, 2001). Such business involved in the production and distribution of information, mainly through mass media, aimed at garnering popular votes.

There are significant differences between commodification of information through mass media and that through social media. The first is often limited to information into media products (in the "hard" form of newspapers or broadcasting programs) to readers or audience. Such commodification through mass media has facilitated the emergence of advertisements that link the audience with media industry and other general industries. This perception suggested two important issues: first, mass media as the sites of information production and second, there a clear connection of the production and consumption of information commodity.

On the contrary, the commodification of social media campaign takes place on social media, whose commodity may not often be seen. The sites of the information production are on social media, developed by social media companies, most prominently Facebook and Twitter that do not produce information as commodity. Instead, they developed the sites that attracted and used by millions of users. These companies generate money from the use of the social media. The bigger the number of users of their social media, the bigger amount of financial gain they receive (Albergotti, MacMillan, \& Rusli, 2014).

Therefore, unlike television audiences, social media users are consumers of social media as well as producers and consumers of social media contents. Social media users as consumers of the technologies are generally not required to pay for using the sites. Likewise, they are not required to pay for the majority of social media contents consumptions. However, the consumption of both social media and social media contents are in fact not entirely free. To be able to consume social media and its pertaining contents, social media users are required to provide the electronic devices such as smart phones or mobile devices - that enables users to get access to the social media -- as well as for the Internet data services to connect with the social media services. These social media users may be anyone from common teenagers, employees to citizens (or voters), politicians and election campaign professionals. Thus, social media contents the users produced may be literally anything, from spontaneous daily talks to crafted commercial messages to deliberated political messages.

\section{Material and Methodology}

This study is a qualitative study to identify and understand certain aspects of social media campaigning practices in Indonesia (Morse \& Niehaus, 2009, p. 15). This case study method involves an in-depth, holistic examination aimed at exploring some aspects of the social media campaigning phenomenon. According to Yin, a case study is "an empirical inquiry that investigates a contemporary phenomenon within its real-life context; when the boundaries between phenomenon and context are not clearly evident; and in which multiple sources of evidence are used" (Yin, 1984: 23).

The case in this study is the gubernatorial election in Jakarta in 2012, which was chosen to explore social media campaigning practices that signifies an arena of contestation involving vast electoral players more receptive to changes in the context of electoral process. In addition, the 
Jakarta election provides a suitable case study mainly because Jakarta is the site of the first acknowledged large-scale social media campaigning in post- authoritarian Indonesia (Ahmad \& Popa, 2014; n.n., 2012). Jakarta is the capital of the country, the home of government offices, national parties' headquarters, local, national and multinational corporations' offices, and local and national media outlets (Okamoto, 2014; Okamoto \& Honna, 2014). The Jakarta gubernatorial elections may be interpreted as the 'barometer' for contests over power across the country (Hui \& Bhakti, 2012).

Table 1. Characteristics of election settings

\begin{tabular}{|l|l|}
\hline \multicolumn{1}{|c|}{ Details } & \multicolumn{1}{c|}{\begin{tabular}{c}
\multicolumn{1}{c|}{ Jakarta Election } \\
\end{tabular}} \\
\hline Eligible voters & $6,962,348\left(1^{\text {st }}\right.$ round $)$ \\
& $6,996,951\left(2^{\text {nd }}\right.$ round $)$ \\
\hline Internet users & $3,500,000$ \\
& $(36.9 \%$ penetration $)$ \\
\hline Number of candidates & 6 pairs $\left(1^{\text {st }}\right.$ round $)$ \\
& 2 pairs $\left(2^{\text {nd }}\right.$ round $)$ \\
\hline
\end{tabular}

Source: KPU DKI Jakarta 2012, APJII 2012

The qualitative informants were selected based on the purpose of this study. The first were mined from industry professionals to examine what they actually did with social media in the context of electoral campaigning. The research was done in Jakarta from August to October, 2013. This study used the in-depth, semistructured interview as the main method to collect data. This method was used with the aim of understanding the views and thoughts of the interviewees regarding their experiences (Fontana \& Frey, 2008). Specifically, it aimed to examine the empirical practices of professionals of the electoral campaign consulting industry in undertaking social mediabased electoral campaign consulting services. This study also conducted a literature study pertaining to the social media, political

Table 2. Total amount of electoral campaign spending (in rupiah)

\begin{tabular}{|l|l|l|l|}
\hline \multicolumn{1}{|c|}{ Election } & $\mathbf{2 0 0 4}$ & $\mathbf{2 0 0 9}$ & $\mathbf{2 0 1 4}$ \\
\hline The Legislative Election* & $297,629,275,399$ & $826,556,080,587$ & $3,109,934,812,094$ \\
\hline The Presidential Election** & $256,350,866,878$ & $576,340,156,985$ & $410,648,064,292$ \\
\hline
\end{tabular}

Source: Supriyanto \& Wulandari (2013: 11-12); KPU (2010); KPU, (2014). The 2004 and 2009 data cover the campaign spending of the 10 biggest political parties, while the 2014 data cover that of 12 political parties. The 2004 presidential election involved 5 candidates, the 2009 election 3 candidates and the 2014 election 2 candidates 
Such increasing electoral spending is driven partly by a post-authoritarian electoral system that requires candidates to garner popular votes in their bid to win the elections, thereby intensifying campaigning efforts. A significant amount of an electoral campaign budget is commonly allocated for media campaigning purposes. One study suggested that 30 percent of campaign budgets is allocated to campaigning through media, mainly television (Mietzner, 2007). A study by anti-corruption organization Indonesian Corruption Watch (ICW) of the campaign spending in the 2004 legislative election, however, showed that the media campaigning budget was mainly allocated for outdoor media, like billboards or leaflets, and radio, instead of print media and television (Badoh \& Dahlan, 2010: 47). Regardless, both studies supported the notion that the economic aspects of the elections had contributed to the flourishing of the political campaign industry in Indonesia (Danial, 2009; Qodari, 2010). While the Internet infrastructure is still developing and the number of users is less than, for example, television, which covers nearly the total population of the archipelago, the emergence of the Internet has further reinforced the expansion of the political campaigning industry.

Although the Internet had been used for political purposes since the late period of the New Order government, it was not until the 2012 Jakarta gubernatorial election that the use of social media was clearly visible in the country's electoral process (Ahmad \& Popa, 2014; Suaedy, 2014). This emergence of the use of social media for electoral campaigning merits further examination for at least two reasons. Firstly, Indonesian politicians and political parties in the early post-authoritarian period, more precisely from 1998-2009, did not appear enthusiastic about using the Internet websites and social media for electoral campaigning (Hameed, 2007; Hill, 2008; Nurhadryani, Maslow, \& Yamamoto, 2009). Studies of this period focused largely on either the Internet penetration or infrastructure and the party organization or individual politicians, without paying much attention to the contributions of the political campaign industry in mediating such use of the Internet and social media.

\section{Commodification of Social Media Campaign}

The commodification of social media campaign could be traced back to the emergence of the political campaign industry, which started to gain its significance after the end of the Suharto government. In the case of Indonesia, it was spurred by the change in election system (Qodari, 2010). Previous elections have witnessed the presence of pollsters notably LP3ES and LSI. Political parties were still fully in charge with the campaign strategy with the help of their campaign teams, which were better known as campaign teams, including members from advertising or public relations industry.

The "official" campaign professionals (other label includes political consultants, campaign strategists, advisor) were not existent until the 2004 election, which was initiated by Lingkaran Survey Indonesia led by US-trained Indonesian researcher Denny Januar Ali (Qodari, 2010, p. 131). Campaign professional groups offered "a full range of services needed to secure the victory of a candidate - from strategic planning, to conceptualizing a candidate's 'vision and mission', from campaigning door to door and designing and organizing media campaigns to providing poll monitors on election day" (Qodari, 2010: 132).

Ufen (2010) suggested that the development of media in Indonesia contributed to both professionalization and commercialization of campaigning. $\mathrm{He}$ concluded the use of television has contributed to the commercialization and professionalization of campaigning, as "the Internet was still of secondary importance for campaigning in the 2009 elections" due low Internet penetration in the country (Ufen, 2010: 21). Furthermore, Indonesian political parties did not bother to allocate sufficient resources e.g. to hire professionals to maintain their 
homepages (Hameed, 2007).

These studies were important to understand the commercial side of the use of Internet technologies in politics. However, the majority of such studies focused more on the involvement of non-party members in running the election campaigns and its pertaining impacts to democracy (Negrine, 2007; Qodari, 2010; Strömbäck, 2009). Thus, it paid little attention on its linkage to the larger political economic process in facilitating the use of social media for campaigning.

This study found that the use of social media in the Jakarta election was not organic. The emergence of social media use was a consequence of the involvement of practitioners from the political campaign industry, who developed and sold social media campaigning services to their clients (mainly the political parties and the candidates). This finding supports the idea that commercial means increasingly play crucial roles in constructing public opinion, particularly in the electoral context (Sussman, 2005). More importantly, it also supports the view that social media have been used for commercial purposes in the context of electoral competition (Trottier \& Fuchs, 2015).

In addition to the nature of social media, there were crucial commercial incentives for the industry to build social media campaigning as profitable services. Firstly, there was a lack of regulation on social media electoral campaigning. The existing law regulating the 2012 Jakarta gubernatorial election did not refer to online electoral campaigning through the Internet or Internet-based platforms. The law merely regulated electoral campaigning through conventional media, which were obliged to provide free and balanced coverage to all candidates in electoral campaigns. The lack of regulation suggested that social media, unlike conventional mass media, were not considered official campaign channels during the 2012 Jakarta election, and thus that the Internet platforms escaped any such requirements set by law. Secondly, social media have the potential to mobilize users; a crucial factor that can be developed into a new service as an alternative to established forms of mass media campaigning. The general perception that campaigning through social media is cheaper than the more expensive forms of mass media contributed to the development of social media campaigning as a new competitive service. This is not to suggest that social media campaigning services are free. After all, social media campaigning services were developed by commercial enterprises for profit, particularly because this development required particular technical expertise that the political parties or politicians do not have. Such development of social media campaigning services represented media commodification as suggested by Mosco (2009).

Those industry professionals who were ready to initiate social media campaigning were those who were optimistic about its prospects in the political campaigning market. Most of these industry professionals involved in the Jakarta elections were working for Jokowi (Kartika Jumadi, personal communication, November 2013). In these Jakarta elections, despite their sometime indifferent attitudes to social media, all candidates nonetheless employed social media as shown in Table 3. 
Table 3. Jakarta Candidates and Modes of Campaign

\begin{tabular}{|c|c|c|c|c|}
\hline Candidates & Consultants & $\begin{array}{l}\text { Offline } \\
\text { Campaign }\end{array}$ & Websites & Social Media \\
\hline $\begin{array}{l}\text { Faisal Basri - } \\
\text { Biem Benyamin }\end{array}$ & 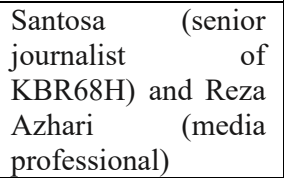 & $\begin{array}{l}\text { Canvassing } \\
\text { Mainstream } \\
\text { media }\end{array}$ & $\begin{array}{l}\text { http://www.faisal } \\
\text { biem.com }\end{array}$ & $\begin{array}{l}\text { Twitter: @FaisalBiem } \\
\text { Facebook: } \\
\text { https://www.facebook.com/faisalbie } \\
\underline{\mathrm{m}}\end{array}$ \\
\hline $\begin{array}{l}\text { Hendarji Supandji - } \\
\text { Riza Patria }\end{array}$ & $\begin{array}{l}\text { Ida Parwati (former } \\
\text { TV presenter), Karel } \\
\text { Susetyo }\end{array}$ & $\begin{array}{l}\text { Canvassing } \\
\text { Mainstream } \\
\text { media }\end{array}$ & $\begin{array}{l}\text { http://hendardjiso } \\
\text { epandji.net }\end{array}$ & $\begin{array}{l}\text { Twitter: @Hendardji74 } \\
\text { Facebook: } \\
\text { https://www.facebook.com/groups/ } \\
\text { hendardji.ariza } \\
\text { https://www.facebook.com/groups/ } \\
2195009527207\end{array}$ \\
\hline $\begin{array}{l}\text { Alex Nurdin }- \text { Nono } \\
\text { Sampono }\end{array}$ & $\begin{array}{l}\text { Lembaga Survei } \\
\text { Indonesia, individual } \\
\text { campaigners }\end{array}$ & $\begin{array}{l}\text { Canvassing } \\
\text { Mainstream } \\
\text { media }\end{array}$ & $\begin{array}{l}\text { http://www.3tahu } \\
\text { nbisa.com } \\
\text { http://alexnono.co } \\
\underline{\mathrm{m}}\end{array}$ & $\begin{array}{l}\text { Twitter@3TahunBisa } \\
\text { Facebook: } \\
\text { https://www.facebook.com/TigaTah } \\
\text { unBisa }\end{array}$ \\
\hline $\begin{array}{l}\text { Hidayat Nur Wahid- } \\
\text { Didik J. Rachbini }\end{array}$ & $\begin{array}{ll}\text { Fortune } & \text { PR, } \\
\text { Individual } & \\
\text { campaigners } & \end{array}$ & $\begin{array}{l}\text { Canvassing } \\
\text { Mainstream } \\
\text { media }\end{array}$ & $\begin{array}{l}\text { http://hidayatdidik } \\
\text { net }\end{array}$ & $\begin{array}{l}\text { Twitter: @hidayatdidik } \\
\text { Facebook: } \\
\text { https://www.facebook.com/hidayat } \\
\text { didik }\end{array}$ \\
\hline $\begin{array}{l}\text { Fauzi Bowo- } \\
\text { Nachrowi Ramli }\end{array}$ & $\begin{array}{l}\text { JSI, } \\
\text { Lingkaran } \\
\text { Indonesia, } \\
\text { Fastcomm, } \\
\text { Sakethi } \\
\text { Consultancy, } \\
\text { Individual campaign } \\
\text { consultants }\end{array}$ & $\begin{array}{l}\text { Canvassing } \\
\text { Mainstream } \\
\text { media }\end{array}$ & $\begin{array}{l}\text { http://www.fauzib } \\
\text { owo.com, } \\
\text { http://web.fauzi- } \\
\text { achrowi.com }\end{array}$ & $\begin{array}{l}\text { Twitter@bangfauzibowo } \\
\text { Facebook: } \\
\text { https://www.facebook.com/ban } \\
\text { gfauzibowo }\end{array}$ \\
\hline $\begin{array}{l}\text { Joko Widodo- } \\
\text { Basuki Tjahaya Purnama }\end{array}$ & $\begin{array}{lr}\text { Cirrus } & \text { Surveyors } \\
\text { Group, } & \text { Cyrus } \\
\text { Network, PolMark, } \\
\text { Individual } \\
\text { campaigners }\end{array}$ & $\begin{array}{l}\text { Canvassing } \\
\text { Mainstream } \\
\text { media }\end{array}$ & $\begin{array}{l}\text { http://jakartabaru. } \\
\text { co, } \\
\text { http://www.jokow } \\
\text { icenter.com } \\
\text { http://ahok.org } \\
\end{array}$ & $\begin{array}{l}\text { Twitter: @JokowiAhok } \\
\text { @Jokowi_do2@basuki_btp } \\
\text { Facebook: } \\
\text { https://www.facebook.com/jokowib } \\
\text { asuki }\end{array}$ \\
\hline
\end{tabular}

Source: Author

In the case of all contestants in the 2012 Jakarta elections, the use of social media for campaigning was initiated and operated by the campaign professionals. However, this chapter argues that economic factors drove the emergence of social media campaigning (Sussman, 2005); rather than the trigger being the lack of expertise of the political parties or candidates to engage with the technical aspects of media technology (Norris, 2000). However, the involvement of practitioners from the political campaign industry in the electoral campaigning operation did not occur automatically. It was initiated by the development of social media campaigning services, including the managing of content, audience or users, and labor. These three aspects defined the significance of social media campaigning services in the electoral process.

\section{Social Media Content}

The production and circulation of campaign messages became a main focus for the campaign industry. The findings of this study contradict arguments that social media articulated a genuine expression of social media users (or volunteers) in the 2012 Jakarta election (Suaedy, 2014). While the findings did not contradict arguments that social media content reflected textual contestation and manipulation (Sadasri, 2016), it found that application of social media to generate content could actually provide a new business opportunity for the industry.

Social media content consists of text, images, videos or memes that are passed from one user to another. Social media content is significant not only because it is a subject of consumption, but also, more importantly, 
production and distribution (as well as reproduction and re-distribution) by social media users (Dean, 2005; Fuchs, 2009). Therefore, the main purpose of social media campaigning is to make campaign issues go viral. Virality refers to a many-to - many, mass-personal communication shaped by various factors, from the characteristics of networks to human attention (Nahon \& Hemsley, 2013). This is the point where the political campaign industry can contribute: generating content that attracts as many users as possible to engage in the production and distribution of the campaign messages.

However, the work of the political campaign industry did not focus on the creation of social media content per se. Instead, their main task was sourcing, curating and managing campaign issues, to maintain the flow of social media content production and distribution throughout the electoral campaign period, until the day of the election. These tasks were to support the strategies dubbed positive and negative campaigning. This refers to electoral campaign messages that highlight the strengths (achievements or personal characteristics deemed supportive of image development) of the candidates, known as positive content; and its converse, the negative content that focuses on campaign messages promoting the weakness (failures or personal characteristics deemed detrimental to image-making) of the contenders.

The significance of the positive and negative campaigning was to encourage users to amass campaign content through social media (see Dean, 2005). It is the interplay between the positive and negative aspects of the candidates that becomes the ground from which the whole electoral campaign is played out in social media. Through positive and negative campaign issues, the industry is able not only to mobilize users to generate content, but more importantly to highlight the visibility of social media content carrying issues during the election that fell into the two categories: supporting the candidates and denouncing their contenders.

During the 2012 Jakarta election, candidate Joko Widodo, or popularly known as
Jokowi, became a target of negative campaigning drives which culminated during the second round of the election (Kusumadewi $\&$ Sodiq, 2012). Most of the issues against him revolved around false accusations about his Muslim credentials or his Javanese background. In contrast, the issues against incumbent Governor Fauzi Bowo, or Foke, were mostly those focussing on the failure of his administration to handle urban problems such as traffic jams and flooding (Haryanto, Theo, \& Malik, 2012).

\section{MobilizingSocial MediaUsers}

The political campaign industry professionals sought to mobilize social media users to engage in the production and distribution of social media content. Analyzing and categorizing interest groups within an electorate is a routine task for political campaign professionals, who seek then to sell candidates to those targeted voters. Mobilizing voters through social media requires "a highly individuated and partisan political climate in which politicians speak through the electorate largely through sound bites that their pollsters' data identify as safe, memorable and marketable" (Sussman, 2005, p. 41).

To mobilize social media users in the proliferation of campaign content supporting their clients, Jakarta-based professional campaigners categorized users into supporters of the candidates, supporters of the contenders, undecided voters and journalists (Kartika Jumadi, personal communication, November 2013). In conventional campaigning, supporters of other candidates were not targeted; due to the assumption that they will never convert their preference. Conventional campaigning through mass media was mainly designed to influence undecided voters and reinforce the supporters of the candidates. The opposite, however, has happened in social media campaigning (Suaedy, 2014: 124). Campaigners target supporters of the contender not necessarily to convert them, but rather to engage them in a cyber campaign war. Such a war (involving the proliferation of social media content that either supports or denounces 
certain candidates) is important for purposes such as opinion reinforcement, mobilization, donation and activism targeted at the candidates' supporters.

Central to what the campaign teams dubbed the 'cyber war' is online activism, which aims to convert interested but passive social media users into activists. This was introduced prominently by professionals working for Jokowi, particularly in the second round of the election in August 2014. The professional campaigners working for Jokowi set up JokowiAhok Social Media Volunteers (JASMEV), a loose volunteer group. This group turned into the first visible online volunteer group during the electoral campaign period in Jakarta. These volunteers comprised mostly students and office employees, who were trained by the professionals to engage in social media campaigning. The training provided meticulous guidance for the volunteers to engage in cyber wars, aimed at both encouraging Jokowi's supporters and provoking supporters of his contenders to join in these cyber wars.

The campaigners did not only prepare campaign issues for the volunteers to discuss on social media, but also instructed them on how to produce social media content based on such issues; and when to post this content. The guidance also outlined how to respond to social media content degrading Jokowi and his deputy candidate. Several campaign teams, including those of Foke and Alex, opted to pay a number of social media users to drive the majority of social media users in their campaigning. Another way of steering social media users to join in social media campaigning was through political party machinery. However, during the Jakarta election, only Partai Keadilan Sejahtera (Prosperous Justice Party - PKS) was able to implement such a strategy. Social media campaigning by Hidayat's team relied heavily on PKS members; however, this failed to attract the attention of other users, partly because they only connected to fellow PKS members on social media. In addition, professionals working for Hidayat did not specifically guide their members on how to engage in social media campaigning (Boy Hamidi, personal communication, October 2013).

Specifically, such "cyber war" was aimed at maintaining the enthusiasm of social media users to continue to produce and distribute electoral content throughout the one-month campaign period. The industry's employment of hash tags on Twitter, for example, reflected its 'cyber war' strategy of inviting users to join in the social media electoral campaign. The first acknowledged Twitter hash tag used in the 2012 Jakarta election was \#ReplaceTitleSongWithJOKOWI to support Jokowi, which became a trending topic in Indonesia during the Jakarta election (Amri et al., 2013). The use of such a strange and politically irrelevant hash tag was aimed at attracting users to participate in social media campaigning, whether consciously or not. This highlights the attempts to engineer content on social media, aimed specifically at mobilizing voters to participate in the production and distribution of content about Jokowi.

\section{Managing Labor}

This study found that social media campaigning generated labor that requires the political campaign industry to manage. The finding contradicts the assertion that social media campaigns which supported candidates were generated by genuine social media volunteers, or, to put it differently, that all social media users were volunteers of the candidates (Suaedy, 2014). The main concerns of this section are the ways in which social media campaigning has enabled new players to enter the campaign consulting business. The industry is a "fluid" one, which welcomes new players with the necessary expertise (Hamburger, 2001; Thurber \& Nelson, 2001). However, the findings of this chapter also suggest that the fluid nature of the industry not only accommodates regular players, such as ICT or communication professionals, but also the likes of unidentified 'buzzers' or influencers running pseudonymous social media accounts to conduct smear campaigns against the candidates.

Social media campaigning introduced 
new form of campaign labor, such as 'buzzing' and social media monitoring. Buzzing refers to the distribution of campaign issues through social media by users with a large network (for example, with a large number of followers on Twitter or 'friends' on Facebook) (Paramadhita, 2013). Such buzzers are perceived to be influential due their ability to reach out and to distribute content to many social media users. In the commercial marketing sector, these users, mainly celebrities with a large number of Twitter followers or Facebook 'friends', often receive financial incentives from advertisers to endorse commercial products. However, such users are not always celebrities or famous people. In the context of electoral campaigning, such individuals have become known as buzzers.

In fact, there were two types of buzzers identified during the Jakarta election. The first category was buzzers unpaid by a campaign team; these were mainly popular celebrities and social activists who supported the candidates. This group commonly supported either Jokowi or Basri. The second category was paid buzzers, who were recruited mainly by the campaign teams of Foke and Alex.

\section{The Emergence of Pseudonymous Buzzers}

In particular, the 2012 Jakarta election marked the emergence of the popular pseudonymous social media buzzers @ triomacan2000 or @kurawa, who drew hundreds of thousands followers, as political buzzers on Twitter. The account of @ triomacan2000, for example, was run for financial purposes by a number of people led by individuals identified as Raden Nuh and Abdul Rasyid, who were graduates of Sumatra Utara University (Yusron, 2012). Raden once served as a commissioner of state-enterprise PT Asuransi Berdikari. Rasyid was on the expert staff of the Coordinating Minister of Economic Affairs, Hatta Radjasa, who was both PAN chairman and father in law of the youngest son of President Susilo Bambang Yudhoyono. The account administrators reportedly threatened Ahok's campaign team that they would buzz smear campaigns against Jokowi and Ahok if the team did not use their buzzing services for Rp 1 billion. The offer was rejected (Amri et al., 2013).

During the election campaign period, @ triomacan 2000 was hired by Foke's campaign team in the second round of the election (Anonymous campaigner, personal communication, November 2013). This account focused on attacking Jokowi's personal life (Sadasri, 2016). Twitter account @kurawa, on the other hand, joined the campaign team of Jokowi in a voluntary capacity, organised by JASMEV. This twitter account was run by a man identified as Rudi Sutanto. In comparison to@triomacan2000,@kurawa focused on uncovering the failures of the Jakarta administration under Foke (Sadasri, 2016).

\section{Social Media Monitoring Services}

Mobilizing social media users requires the industry to monitor the behavior of social media users closely during the electoral campaign period. The emergence of social media monitoring services fulfilled such a need; tracing not only social media users' behavior and candidate preferences, but also their possible changes in behavior and preferences. Such information enables the political contenders to develop a social media campaign strategy and monitor the social media components so as to win the "cyber campaign war'. This service represented immanent commodification, which is defined as "how commodities produce their own new commodities, and how new commodities are produced through the association among different commodities" (Mosco, 2009: 141). Social media monitoring is on a par with the significance of audience ratings in the commodification of conventional media, which "demands the use of measurement procedures to produce commodities and monitoring techniques to keep track of production, distribution, exchange and consumption" (Mosco, 2009: 141).

A social media monitoring service is enabled by a search engine trawling through a 
mass of content from the Internet and social media. The machine commonly uses certain keywords relevant to the candidates to mine millions of items of social media. It is able to analyze this big data to extract the information necessary for social media campaigning strategy making (see Table 4). During the 2012 Jakarta election, it was only Jokowi's personal campaign team that employed such services. The companies that provided the services were Katapedia and Politicawave. Their services involved presenting the results of social media monitoring regularly (daily, weekly or during a certain period prior to crucial times such as televised gubernatorial debates) to other strategists tasked with managing campaign issues.

These companies were among the first Indonesian Internet monitoring companies to become involved formally in a political campaign. This particular service of social media monitoring gained public attention following their accurate prediction that Jokowi would win the election, which was against the forecast of conventional pollsters in the first round of the election.

Table 4. Social media measurement methods

\begin{tabular}{|l|l|}
\hline Method & Function \\
\hline Sentiment index & $\begin{array}{l}\text { To measure and compare the sentiment of social media users toward } \\
\text { candidates }\end{array}$ \\
\hline Unique user & $\begin{array}{l}\text { To measure the number of unique accounts involved in a social media } \\
\text { conversation about a certain brand (or candidate) during a certain period of } \\
\text { time. This is equal to 'media reach' in conventional media as an } \\
\text { effectiveness measurement }\end{array}$ \\
\hline Brend of awareness & $\begin{array}{l}\text { To measure the number of social media conversations about a brand (or } \\
\text { candidate) during a certain period of time }\end{array}$ \\
\hline Candidate electability & $\begin{array}{l}\text { To measure the level of buzz about all candidates during a certain period } \\
\text { of time }\end{array}$ \\
\hline Share of awareness & $\begin{array}{l}\text { To measure the position of a candidate compared to other candidates } \\
\text { during a certain period of time }\end{array}$ \\
\hline Earned media of product & $\begin{array}{l}\text { To measure the percentage of buzz of every candidate during a certain } \\
\text { period of time }\end{array}$ \\
\hline Share of citizen & $\begin{array}{l}\text { To measure the share of sentiment in conversations about a brand (or a } \\
\text { candidate) against other brand (or other candidate) during a certain } \\
\text { category (or election) }\end{array}$ \\
\hline $\begin{array}{l}\text { To measure the percentage of unique users involved in social media } \\
\text { conversations about every candidates }\end{array}$ \\
\hline Politicawave $(2014)$.
\end{tabular}

Source: Politicawave (2014).

Such a service is essentially a form of immanent commodification, referring to commodities that may produce their own new commodities (Mosco, 2009). The most popular example of immanent commodification in conventional media is audience rating, which refers to a measurement of viewership of a particular television program.

\section{Conclusion}

This study has shown that the commodification of social media by the political campaign industry played important roles in facilitating political elite's use of social media in Indonesian election campaigns. Social media has enabled exchange value production of election information by turning election-related information into marketable commodity in 
election campaigns. In addition, this form of commodity has triggered the production of a new commodity by name of social media monitoring as seen in the establishment and growth of social media monitoring business.

The social media use in Indonesian election campaigns were shaped by both market pressures, which was represented by the increasing number of social media users, and political cultures within the context of postauthoritarian state. The commodification of social media in election campaigns should be seen as a logical consequence of the general economic social and politics transformation after the end of the authoritarian period. The 2012 Jakarta election may be seen as a pioneer site of commodification, which later spread to other electoral scenes in Indonesia.

The social media-enabled commodification of election information reached a new height with the intensified works of social media users management and the establishment of new social media monitoring companies. Social media could then be seen for enabling election information to be made a commodity, financially paid for by the politician, consumed and produced by voters, organized and shaped by the social media entrepreneurs or practitioners.

\section{References}

Ahmad, N., \& Popa, I. L. (2014). The social media usage and the transformation of political marketing and campaigning of the emerging democracy in Indonesia: Case study of the 2012 gubernatorial election of the Special Region of the Capital City Jakarta. In B. Pătruţ \& M. Pătruţ (Eds.), Social Media in Politics: Case Studies on the Political Power of Social Media (pp. 97-125). Cham, Zwitzerland: Springer International Publishing.

Albergotti, R., MacMillan, D., \& Rusli, E. M. 2014. Facebook to pay $\$ 19$ billion for WhatsApp messaging startup to operate independently, retain brand. The Wall Street Journal. Retrieved from The Wall
Street Journal Online website:

http://online.wsj.com/news/articles/SB10

001424052702304914204579393452029 288302

Amri, A. B., Ruqoyah, S., Nurbaya, R., Afrisia, R.S., Wibowo, T. A., Akbar, R. J., \& Ansyari, S. (2013). Memburu @TrioMacan2000. viva.co.id. Retrieved from Viva.co.id website: http://sorot.news.viva.co.id/news/read/41 5644memburu--triomacan2000

-Ben-Porat, A. 1998. The Commodification of Football in Israel. International Review for the Sociology of Sport, Vol. 33(3): 269-276.

Danial, A. (2009). Iklan politik TV: Modernisasi Kampanye Politik Pasca Orde Baru (TV Political Advertising: The Modernisation of Political Campaign Post-New Order). Yogyakarta: PT LKiS Pelangi Aksara.

Grigsby, M. 1998. Sailormoon: Manga (Comics) and Anime (Cartoon) Superheroine Meets Barbie: Global Entertainment Commodity Comes to the United States. The Journal of Popular Culture, Vol. 32(1): 59-80.

Hameed, S. S. (2007). Internet Deployment in the 2004 Indonesian Presidential Elections. In R. Kluver, N. W. Jankowski, K. A. Foot, \& S. M. Schneider (Eds.), The Internet and National Elections: A Comparative Study of Web Campaigning, Vol. 2: 194-209. Milton Park, Abingdon, OX: Routlege.

Hamburger, M. (2001). The Business of Political Consulting. In J. A. Thurber \& C. J. Nelson (Eds.), Campaign warriors: The roles of political consultants in election (pp. 36-52). Washington D.C.: Brookings Institution Press.

Hill, D. T., \& Sen, K. (2000). The Internet in Indonesia's New Democracy. Democratization, Vol. 7(1): 119-136.

Hui, Y. F., \& Bhakti, I. N. (2012). The Gubernatorial Race in Jakarta: Background and Implications. ISEAS Perspective, 1-5. Retrieved from ISEAS website:http://www.iseas.edu.sg/documen 
ts/publication/IS.AS.Perspective_1nov12. $p d f$

Ibrahim, M., Abdillah, O., Wicaksono, A. F., \& Adriani, M. (2015). Buzzer Detection and Dentiment Analysis for Predicting Presidential Election Results in a Twitter Nation. Paper presented at the 2015 IEEE International Conference on Data Mining Workshop, Atlantic City, New Jersey.

Kotler, P., \& Kotler, N. (1999). Political Marketing: Generating Effective Candidates, Campaigns and Causes. In B. I. Newman (Ed.), Handbook of political marketing (pp. 3-18). Thousand Oaks, CA: Sage Publications, Inc.

Kusumadewi, A., \& Sodiq, F. (2012). Jokowi Dukung Deklarasi Anti Isu SARA (Jokowi Supports the Seclaration Anti SARA Issues). viva.co.id. Retrieved from: http://news.viva.co.id/pages/tentangkami

Mancini, P. (2011). Between Commodification and Lifestyle Politics: Does Silvio Berlusconi Provide a New Model of Politics for the Twenty-first Century? Oxford: Oxford: Reuters Institute for the Study of Journalism, University of Oxford.

McKay, J., \& Miller, T. (1991). From Old Boys to Men and Women of the Corporation: The Americanization and Commodification of Australian Sport. Sociology of Sport Journal, Vol. 8(2): 8694.

Ufen, A. (2010)a. Electoral campaigning in Indonesia: The Professionalization and Commercialization After 1998. Journal of Current Southeast Asian Affairs, Vol. 29(4): 11-37.

Ufen, A. (2010)b. Forms of Campaigning and the Transformation of Political Parties in Indonesia. LSE Ideas Special Report: Democratisation \& New Voter Mobilisation in Southeast Asia. Retrieved from:

http://www.lse.ac.uk/IDEAS/publications/ reports/pdf/SR005/Indo_Ufen.pdf

Mietzner, M. (2007). Party Financing in PostSoeharto Indonesia: Between State
Subsidies and Political Corruption. Journal of International and Strategic Affairs, Vol. 29(2), 238-263.

Mietzner, M. (2008). Soldiers, Parties and Bureaucrats: Illicit Fund-raising in Contemporary Indonesia. South East Asia Research, Vol.16(2), 225-254.

Morse, JM \& Niehaus, L. (2009). Principles and Procedures of Mixed Methods Mesign. Left Coast Press. Walnut Creek.

Mosco, V. (2009). The Political Economy of Communication. London \& Thousand Oaks: Sage Publications.

Nahon, K., \& Hemsley, J. (2013). Going Viral. Cambridge: Polity.

Negrine, R. M., \& Stanyer, J. (2007). The Political Communication Reader. New York: Routledge.

Nurhadryani, Y. Maslow, S., \& Yamamoto, H. (2009). Democracy 1.0 Meets 'Web 2.0: E-Campaigning and the Role of ICTs in Indonesia's Political Reform Process Since 1998. Interdisciplinary Information Sciences, Vol. 15(2): 211-222.

Nuswantoro, A. R. (2014). Kelas menengah dan Kondisi Deliberatif: Pertukaran Informasi Kompasianer pada Masa Kampanye Pilkada DKI Jakarta 2012 dan Pemenuhannya terhadap Kondisi Deliberatif (Middle Class and Deliveratice Conditions: The Kompasianer's Excange of Information During the Campaign Period of the 2012 DKI Jakarta Local Election and its Fullfillment of the Feliverative Conditions). Thesis, Universitas Gadjah Mada, Yogyakarta.

Okamoto, M., \& Honna, J. (2014). "Local" Politics in Jakarta: Anomaly from Indonesia's Local Politics? Journal of Current Southeast Asian Affairs, Vol. 33(1): 3-6.

Paramadhita, R. (2013). In Indonesia, Buzzers are not Heard But Tweet for Money. Reuters.

Petrocik, J. R. (1996). Issue Ownership in Presidential Elections, With a 1980 Case Study. American Journal of Political Science, Vol., 40(3): 852-850. 
Petrocik, J. R., Benoit, W. L., \& Hansen, G. J. (2003). Issue Ownership and Presidential Campaigning. Political Science Quarterly, Vol. 118(4): 599-626.

Qodari, M. (2010). The Professionalisation of Politics: The Growing Role of Polling Organisations and Political Consultants. In M. Mietzer \& E. Aspinall (Eds.), Problems of democratisation in Indonesia: Elections, institutions and society (pp. 122-140). Singapore: ISEAS.

Sadasri, L. M. 2016. Micro-celebrity: Menakar Kajian Ilmu Komunikasi dalam Media Baru. In W. M. Santoso (Ed.), Ilmu Sosial di Indonesia: Perkembangan dan Tantangan (pp. 433-454). Jakarta: Yayasan Pustaka Obor.

Sobri, A. (2012). Donasi Online Biayai Kampanye Faisal-Biem (Online donation funds Faisal-Biem campaign). Kompas.com. Retrieved from http://www.kompas.com website: http://health.kompas.com/read/2012/06/2 6/19334856/Donasi.Online.Biayai.Kamp anye.Faisal-Biem

Stiernstedt, F. (2008). Maximizing the Power of Entertainment. The Audience Commodity in Contemporary Radio. Radio Journal: International Studies in Broadcast \& Audio Media, Vol.2(2-3): 11-127.

Suaedy, A. (2014). The Role of Volunteers and Political Participation in the 2012 Jakarta Gubernatorial Election. Journal of Current Southeast Asian Affairs, Vol.33(1): 111-138.

Sussman, G. (2005). Global Electioneering: Campaign Consulting, Communications, and Corporate Financing: Rowman \& Littlefield.

Syahputra, I. (2017). Demokrasi Virtual dan Perang Siber di Media Sosial: Perspektif Netizen Indonesia. Jurnal ASPIKOM Jurnal Ilmu Komunikasi, Vol.3(3): 457475.

Strömbäck, J. 2009. Selective Professionalisation of Political Campaigning: A Test of the Party-centred Theory of Professionalised Campaigning in the Context of the 2006 Swedish Election. Political Studies, Vol. 57(1): 95116.

Supriyanto, D., \& Wulandari, L. (2013). Basabasi Dana Kampanye. Pengabaian Prinsip Transparansi dan Akuntabilitas Peserta Pemilu (Campaign Budget Chit Chat. The Abandonment of the Principles of Transparency and Accountability of Election Participants). Jakarta: Perkumpulan untuk Pemilu dan Demokrasi.

Thurber, J. A., \& Nelson, C. J. (2001). Campaign Warriors: The Role of Political Consultants in Elections: Brookings Institution Press.

Trent, J. S., \& Friedenberg, R. V. (1995). Political Campaign Communication: Principles and Practices (Third Edition). Westport, Connecticut: Praeger.

Ufen, A. (2010)a. Electoral Campaigning in Indonesia: The Professionalization and Commercialization After 1998. Journal of Current Southeast Asian Affairs, Vol. 29(4): 11-37.

Ufen, A. (2010)b. Forms of Campaigning and the Transformation of Political Parties in Indonesia. LSE Ideas Special Report: Democratisation \& New Voter Mobilisation in Southeast Asia. Retrieved from:

http://www.lse.ac.uk/IDEAS/publications /reports/pdf/SR005/Indo Ufen.pdf

Utomo, W. P. (2013). Menimbang Media Sosial dalam Marketing Politik di Indonesia: Belajar dari Jokowi-Ahok di Pilkada DKI Jakarta 2012 (Weighing Social Media in Political Marketing in Indonesia: Learning From Jokowi-Ahok in the 2012 DKI Jakarta Local Election). Jurnal Ilmu Sosial dan Ilmu Politik, Vol. 17(1): 67-84.

Wijayanto, A. (2010). Social Networking Sites, Komunikasi Politik dan Akurasi Prediksi dalam Pemilihan Presiden di Indonesia (Social Networking Sites, Political Communication and Prediction Accuration in the Presidential Election in Indonesia). Forum, Vol. 38(1): 24-30. 
Yin, R. K. (1984). Case Study Research: Design and Methods. Beverly Hills: Sage Publications.

Yuliatiningtyas, S. (2014). Campaign Strategies of Political Parties in the 2014 Presidential Election in Indonesia. Paper presented at the The 2014 Australian Political Studies Association Annual Conference, Sydney.
Yusron, U. (2012). Wawancara Eksklusif dengan Raden Nuh, Admin Akun @TrioMacan2000. Beritasatu.com. Retrieved from Beritasatu.com website: http://www.beritasatu.com/nasional/8299 1 wawancara-eksklusif-dengan-radennuh-adminakun-triomacan2000.html 